\title{
Evolution of Complex Phases in Al-Fe-Si Systems
}

\author{
Juraj Zigo *, Peter Svec ${ }^{a}$, Dusan Janickovic ${ }^{a}$, Irena Janotova ${ }^{a}$, \\ Igor Matko ${ }^{a}$, Marek Mihalkovic ${ }^{a}$,Peter Svec Sra
}

${ }^{a}$ Institute of Physics, Slovak Academy of Sciences - SAV, Dubravska cesta 9, 84511 Bratislava, Slovakia

Received: October 27, 2014; Revised: July 9, 2015

\begin{abstract}
Phase transformations and composition of Al-Fe-Si, $\mathrm{Al}-\mathrm{Co}-\mathrm{Si}$ and $\mathrm{Al}-\mathrm{Ni}$-Si based rapidly quenched ribbons have been investigated. Different $\mathrm{Al}-\mathrm{Si}$ based alloys with varying $\mathrm{Si}$ content and additions of third metallic element, namely $\mathrm{Al}_{80} \mathrm{Si}_{20}, \mathrm{Al}_{60} \mathrm{Si}_{40}, \mathrm{Al}_{75} \mathrm{Fe}_{5} \mathrm{Si}_{20}, \mathrm{Al}_{70} \mathrm{Fe}_{10} \mathrm{Si}_{20}, \mathrm{Al}_{75} \mathrm{Co}_{5} \mathrm{Si}_{20}, \mathrm{Al}_{70} \mathrm{Co}_{10} \mathrm{Si}_{20}$, $\mathrm{Al}_{75} \mathrm{Ni}_{5} \mathrm{Si}_{20}, \mathrm{Al}_{70} \mathrm{Ni}_{10} \mathrm{Si}_{20}$ were analyzed. Variation of phase composition with elemental composition was observed. Evolution of phases was determined by resistometry, differential scanning calorimetry (DSC). In situ X-ray diffraction (XRD) and transmission electron microscope (TEM) records were observed during isothermal and isochronal annealing.
\end{abstract}

Keywords: metallic glasses, planar flow casting, amorphous materials, aluminum-silicon alloys, nanocrystalline structure

\section{Introduction}

Conventional aluminum alloys are widely used for good mechanical properties and relatively light weight. Enhancing these properties could be made by alloying aluminum with various elements such as silicon, which is reasonable choice in terms of sustaining light weight properties. Producing Al-Si alloy with higher silicon content cannot be achieved by conventional metallurgy. Even by rapid quenching, only up to few weight percent of $\mathrm{Si}$ content has been attained in binary Al-Si alloys. It was found that increasing content of dissolved silicon is possible by adding other alloying components. Candidates with respect to low specific mass are transition elements of $4^{\text {th }}$ period (from scandium to zinc).

We have chosen to investigate rapidly quenched alloys of Al-Si with transition elements ( $\mathrm{T}$ ) iron, cobalt and nickel. Composition of the investigated systems was $\mathrm{Al}_{80-\mathrm{x}} \mathrm{T}_{x} \mathrm{Si}_{20}$ where $\mathrm{T}=\mathrm{Fe}, \mathrm{Co}, \mathrm{Ni}$ and $\mathrm{x}=0,5$ and 10 .

\section{Experimental Details}

Rapidly quenched ribbons consisting of $\mathrm{Al}-\mathrm{Si}, \mathrm{Al}-\mathrm{Fe}-\mathrm{Si}$, Al-Co-Si and Al-Ni-Si (namely $\mathrm{Al}_{80} \mathrm{Si}_{20}, \mathrm{Al}_{60} \mathrm{Si}_{40}, \mathrm{Al}_{75} \mathrm{Fe}_{5} \mathrm{Si}_{20}$, $\mathrm{Al}_{70} \mathrm{Fe}_{10} \mathrm{Si}_{20}, \mathrm{Al}_{75} \mathrm{Co}_{5} \mathrm{Si}_{20}, \mathrm{Al}_{70} \mathrm{Co}_{10} \mathrm{Si}_{20}, \mathrm{Al}_{75} \mathrm{Ni}_{5} \mathrm{Si}_{20}, \mathrm{Al}_{70} \mathrm{Ni}_{10} \mathrm{Si}_{20}$ ) have been prepared by the planar flow casting (PFC) technique. During PFC, the melt is pressed by gas pressure through a nozzle on a surface of a fast rotating copper wheel. This allows the melt to solidify in a very short time of few $\mu$ s. Final product obtained this way is a $20-40 \mu \mathrm{m}$ thick amorphous, or in some cases nanocrystalline or polycrystalline ribbon with widths ranging from few $\mathrm{mm}$ to tens of $\mathrm{mm}$. This structure can be further heat treated, while observing its physical properties. Changes in physical properties such as relative electrical resistivity and heat evolution are indicators of ongoing phase transformations. Structural properties before, during and after heat treatment can be for example observed by

*e-mail: juraj.zigo@savba.sk
$\mathrm{X}$-ray diffraction, transmission electron microscopy (TEM) or electrical resistivity measurements.

Change of resistivity of the ribbons was measured during linear heating. Relative resistivity was acquired using resistivity bridge (Linear Research LR-100). Samples were heat treated in planar furnace with high spatial uniformity of temperature in argon atmosphere.

Differential scanning calorimetry was used to determine heat flow during linear heating of samples using DSC Perkin-Elmer 8500.

Eventual variation of magnetic properties with heating was examined by thermogravimetric analysis using PerkinElmer TGA 7 with a small magnet $(\sim 20 \mathrm{mT})$.

Content of various phases in samples was examined using X-ray diffraction or in-situ X-ray diffraction. Samples have been examined in as-cast state, after heat treatment or during linear heating using Bruker D8 Advance powder diffractometer with $\mathrm{Cr} \mathrm{K}$-alpha radiation. In-situ XRD patterns were obtained sequentially during linear heating.

Microstructure of samples was investigated using in-situ transmission electron microscopy (JEOL 2000FX at $200 \mathrm{kV}$ ). Micrographs were obtained during linear heating of sample in hot stage. Electron diffraction was used to determine phases present in the as-quenched state or during heat treatment.

\section{Results}

Samples in as-quenched state were analyzed by XRD to determine their state and phase composition.

Figure 1 shows diffraction patterns of $\mathrm{Al}-\mathrm{Fe}-\mathrm{Si}, \mathrm{Al}-\mathrm{Co}-\mathrm{Si}$, $\mathrm{Al}-\mathrm{Ni}-\mathrm{Si}$ and $\mathrm{Al}-\mathrm{Si}$ alloys. Reference alloy $\mathrm{Al}_{60} \mathrm{Si}_{40}$, shows mainly content of fcc-Al and Si.

The content of Si phase significantly decreases already with addition of 5 at. $\%$ of transition element, as is clearly visible by the decreases of the intensity of Si diffraction 
maxima. Specifically, $\mathrm{Al}_{75} \mathrm{Co}_{5} \mathrm{Si}_{20}$ still shows content of mainly fcc-Al and Si phases, but the content of Si phase is decreased. We also detected content of various Al-Co and Al-Si phases, such as $\mathrm{Al}_{0.52} \mathrm{Co}_{0.48}, \mathrm{Al}_{0.96} \mathrm{Co}_{1.04}$ and $\mathrm{Al}_{3.21} \mathrm{Si}_{0.47}$. For $\mathrm{Al}_{75} \mathrm{Fe}_{5} \mathrm{Si}_{20}$, we also detected fcc-Al phase, Si phase as well as a rather interesting $\mathrm{Al}_{3.21} \mathrm{Si}_{0.47}$ complex Al-based phase ${ }^{1}$. Similar results were obtained for $\mathrm{Al}_{75} \mathrm{Ni}_{5} \mathrm{Si}_{20}$, together with

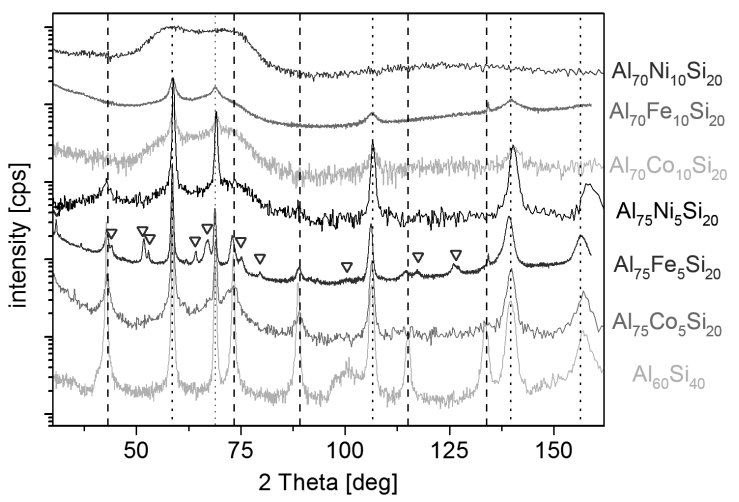

Figure 1. X-ray diffraction patterns of as-quenched alloys. Dotted lines mark fcc-Al phase peaks, dashed lines mark Si phase peaks. Upside-down triangles mark peaks of complex Al-based phases. broader diffraction maxima, which suggest certain amount of amorphous or disordered phase.

Content of $\mathrm{Si}$ as a phase is decreased even more by adding 10 at.\% of transition element. Phase composition becomes more simple and the content of amorphous phase is increased as demonstrated in Figure 1. Analysis of $\mathrm{Al}_{70} \mathrm{Co}_{10} \mathrm{Si}_{20}$ and $\mathrm{Al}_{70} \mathrm{Fe}_{10} \mathrm{Si}_{20}$ shows comparable results - amorphous plateau around $2 \theta$ angles $50-90^{\circ}$ and minor maxima assigned to crystalline fcc-Al. For $\mathrm{Al}_{75} \mathrm{Ni}_{5} \mathrm{Si}_{20}$, bimodal broad plateau is present, which can be a signature of either ultrafine nanocrystalline grains of $\mathrm{Al}$ or of phase separation in amorphous state similar to that observed in bulk metallic glasses ${ }^{2}$.

To examine alloy thermodynamic and reaction kinetic properties, relative electrical resistivity (Figure 2) and DSC measurements (Figure 3) during heating were performed. Alloys of $\mathrm{Al}_{80} \mathrm{Si}_{20}$ and $\mathrm{Al}_{75} \mathrm{Co}_{5} \mathrm{Si}_{20}$ showed steep slope of $\mathrm{R}(\mathrm{T}) / \mathrm{R}(300 \mathrm{~K})$ (high temperature coefficient of resistivity), which is evidence of polycrystalline structure.

Compared to that, alloys with composition of $\mathrm{Al}_{75} \mathrm{Ni}_{5} \mathrm{Si}_{20}$, $\mathrm{Al}_{70} \mathrm{Ni}_{10} \mathrm{Si}_{20}$ and $\mathrm{Al}_{70} \mathrm{Co}_{10} \mathrm{Si}_{20}$ have much lower temperature coefficient of resistivity, for $\mathrm{Al}_{70} \mathrm{Ni}_{10} \mathrm{Si}_{20}$ and $\mathrm{Al}_{70} \mathrm{Co}_{10} \mathrm{Si}_{20}$ even with negative value. Complicated evolution of resistivity of $\mathrm{Al}_{75} \mathrm{Ni}_{5} \mathrm{Si}_{20}, \mathrm{Al}_{70} \mathrm{Ni}_{10} \mathrm{Si}_{20}$ and $\mathrm{Al}_{70} \mathrm{Co}_{10} \mathrm{Si}_{20}$, is evidence of ongoing phase transformations from metastable state during
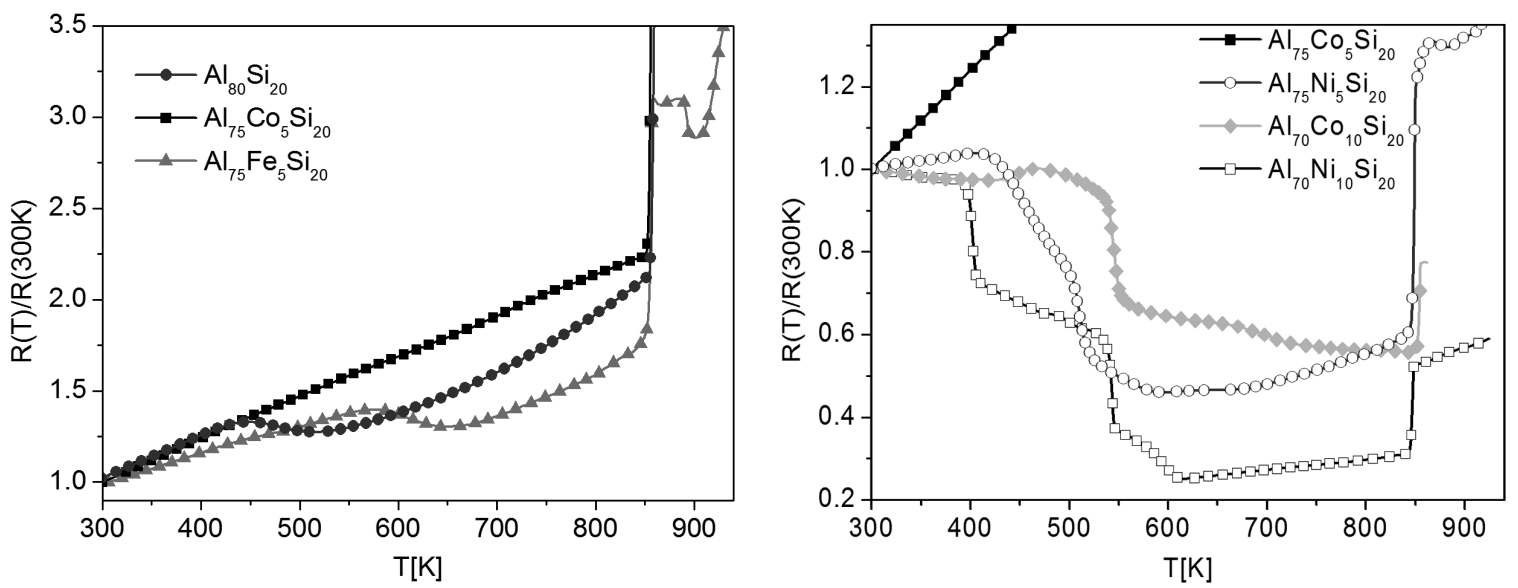

Figure 2. Temperature dependence of relative electrical resistivity (linear heating $10 \mathrm{~K} / \mathrm{min}$ ).
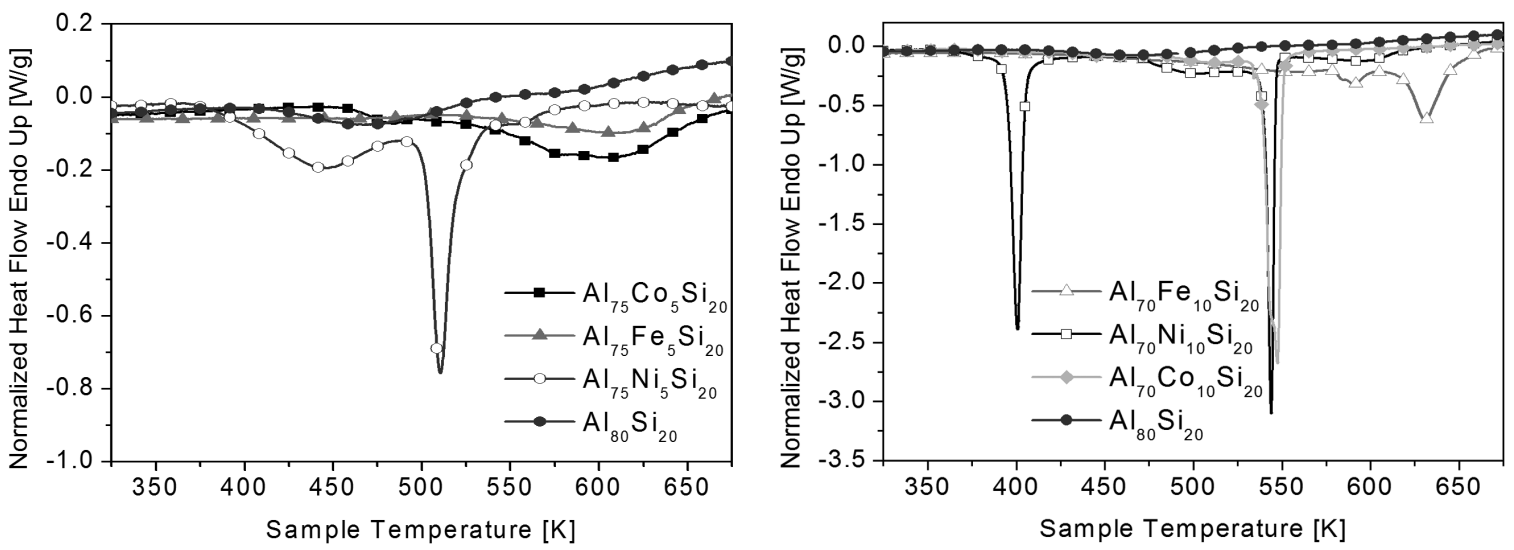

Figure 3. DSC measurement (linear heating $10 \mathrm{~K} / \mathrm{min}$ ). 
heating. Nearly vertical step present in all curves at high temperatures corresponds to melting of Al phase.

Subsequently to these measurements, we were interested in evolution of phases which might occur during phase transformations. In-situ XRD and TEM was used in this manner in order to map and image phase composition changes during heating.

In-situ TEM analysis was used for $\mathrm{Al}_{75} \mathrm{Ni}_{5} \mathrm{Si}_{20}$ and $\mathrm{Al}_{70} \mathrm{Ni}_{10} \mathrm{Si}_{20}$ alloys. These are the most interesting systems from the viewpoint of phase transformations and as-cast state. Phase composition changes during heat treatment occurred in both cases at temperatures expected from resistivity and DSC measurements (Figures 2 and 3). Micrographs of as-cast $\mathrm{Al}_{75} \mathrm{Ni}_{5} \mathrm{Si}_{20}$ (Figure 4) shows mixed amorphous and crystalline phases, as was expected from the slope of resistivity curve. In as-cast state, amorphous-like regions surrounded by mixed amorphous and crystalline regions were observed.

These seem to be morphologically similar to structures referred to as q-glass, which were observed in rapidly quenched alloys of Al-Fe-Si. Q-glass is presumed to grow like a crystal, while being isotropic ${ }^{3}$. During heating to $500 \mathrm{~K}$ (Figure $4 \mathrm{~b}$ ), growth of fcc-Al( $\mathrm{Si}, \mathrm{Ni})$ nanocrystals took place. With heating to $600 \mathrm{~K}$ (Figure 4c) further growth of Al-grains and their coalescence took place. Continued heating between 600 and $800 \mathrm{~K}$ (Figure 4d) lead to further coarsening of the fcc-Al phase and to formation of additional intermetallic phases.

In case of $\mathrm{Al}_{70} \mathrm{Ni}_{10} \mathrm{Si}_{20}$, similar results were obtained. In as-cast state, two different types of morphology were observed. Figure 5a shows fine crystalline region without amorphous phase (consisting mainly of fcc-Al, $\mathrm{Al}_{3} \mathrm{Ni}, \mathrm{NiSi}_{2}$ and $\mathrm{Al}_{9} \mathrm{Si}$ ), while Figure $5 \mathrm{~b}$ shows amorphous region similar to that observed in $\mathrm{Al}_{75} \mathrm{Ni}_{5} \mathrm{Si}_{20}$. During heating to $610 \mathrm{~K}$, phase transformations and growth of grains took place. With further heating to $800 \mathrm{~K}$, further coarsening of fcc-Al phases was observed with resulting $\mathrm{Al}_{3} \mathrm{Ni}, \mathrm{Si}$ and fcc-Al composition.

Evolution of phase composition of $\mathrm{Al}_{70} \mathrm{Fe}_{10} \mathrm{Si}_{20}, \mathrm{Al}_{70} \mathrm{Ni}_{10} \mathrm{Si}_{20}$ and $\mathrm{Al}_{75} \mathrm{Ni}_{5} \mathrm{Si}_{20}$ was observed by in-situ XRD. XRD was cyclically measured in range of $2 \theta$ angles from 50 to $80^{\circ}$ at temperatures from $320 \mathrm{~K}$ to $850 \mathrm{~K}$. These measurements, displayed in Figure 6, clearly show transformations of XRD patterns at temperatures corresponding to transformation temperatures measured by DSC or relative resistivity measurement. $\mathrm{Al}_{70} \mathrm{Fe}_{10} \mathrm{Si}_{20}$ (Figure 6a) in as-cast state shows partly amorphous structure mixed with fcc-Al phase (fcc-Al peaks are marked by black dotted lines). During heating, it transforms to form polycrystalline pattern with fcc-Al and Si peaks. $\mathrm{Al}_{70} \mathrm{Ni}_{10} \mathrm{Si}_{20}$ (Figure 6b) is amorphous in as-cast state. During heating, it transforms in several stages to form fcc-Al and $\mathrm{Al}_{3} \mathrm{Ni}$ phases ${ }^{4} . \mathrm{Al}_{75} \mathrm{Ni}_{5} \mathrm{Si}_{20}$ (Figure $6 \mathrm{c}$ ) transforms from mixed amorphous and crystalline (consisting mainly fcc-Al) state to form fcc-Al, $\mathrm{Al}_{3} \mathrm{Ni}$ and $\mathrm{Si}$ phases.

More detailed view on how $\mathrm{Al}_{70} \mathrm{Ni}_{10} \mathrm{Si}_{20}$ XRD pattern is changing with temperature is presented on Figure 7, which displays XRD patterns in as-cast state and annealed to selected temperatures from $448 \mathrm{~K}$ to $763 \mathrm{~K}$.

To review potential (ferro)magnetic properties of alloys, M-TGA measurement have been made. Data acquired by this technique are displayed on Figure 8, which show nearly no variation of magnetic properties with temperature comparable to instrument baseline.
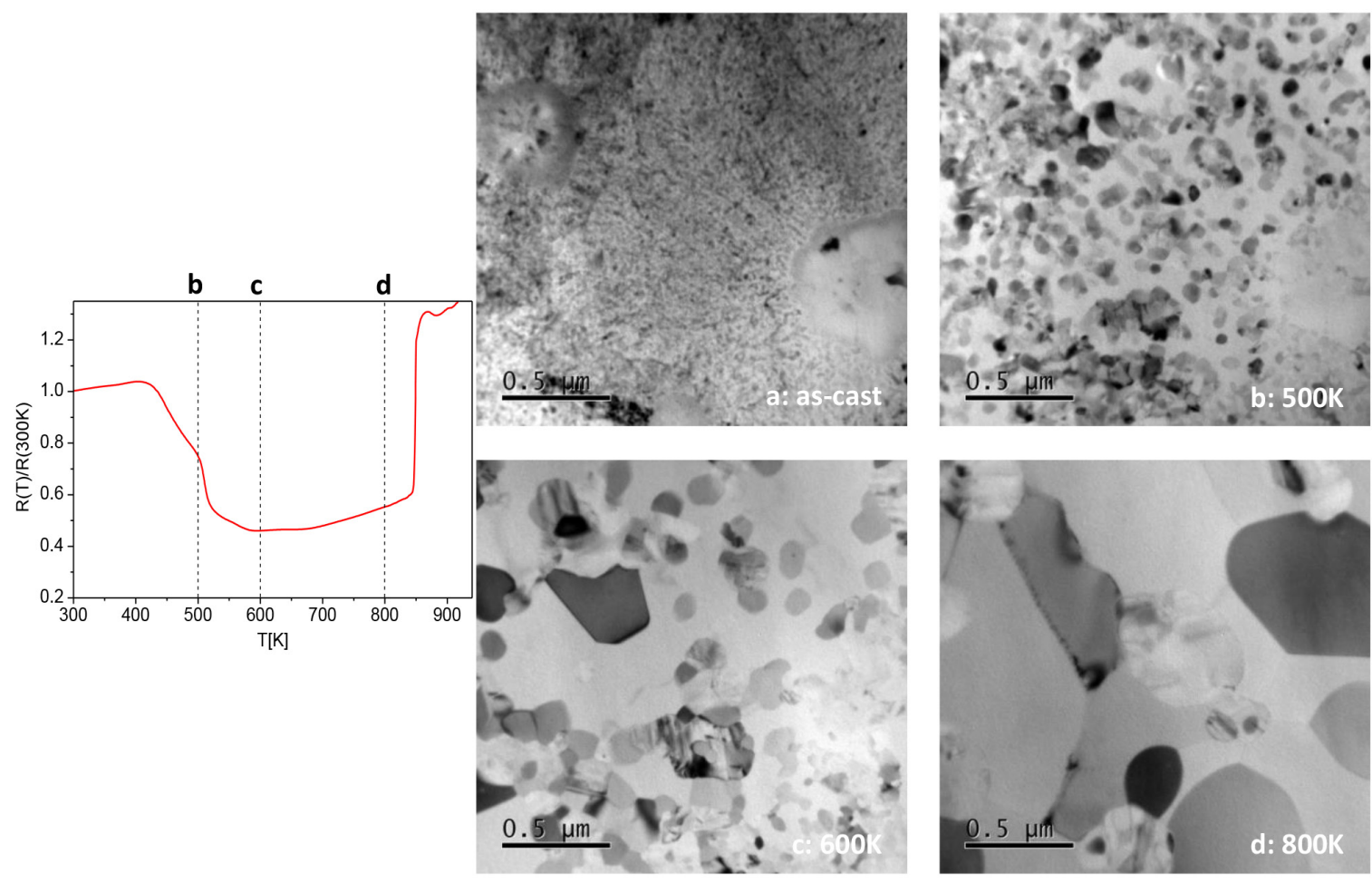

Figure 4. TEM micrographs of $\mathrm{Al}_{75} \mathrm{Ni}_{5} \mathrm{Si}_{20}$ alloy in as-cast state (a), and during in-situ heat treatment at $500 \mathrm{~K}$ (b), $600 \mathrm{~K}$ (c) and $800 \mathrm{~K}$ (d). 


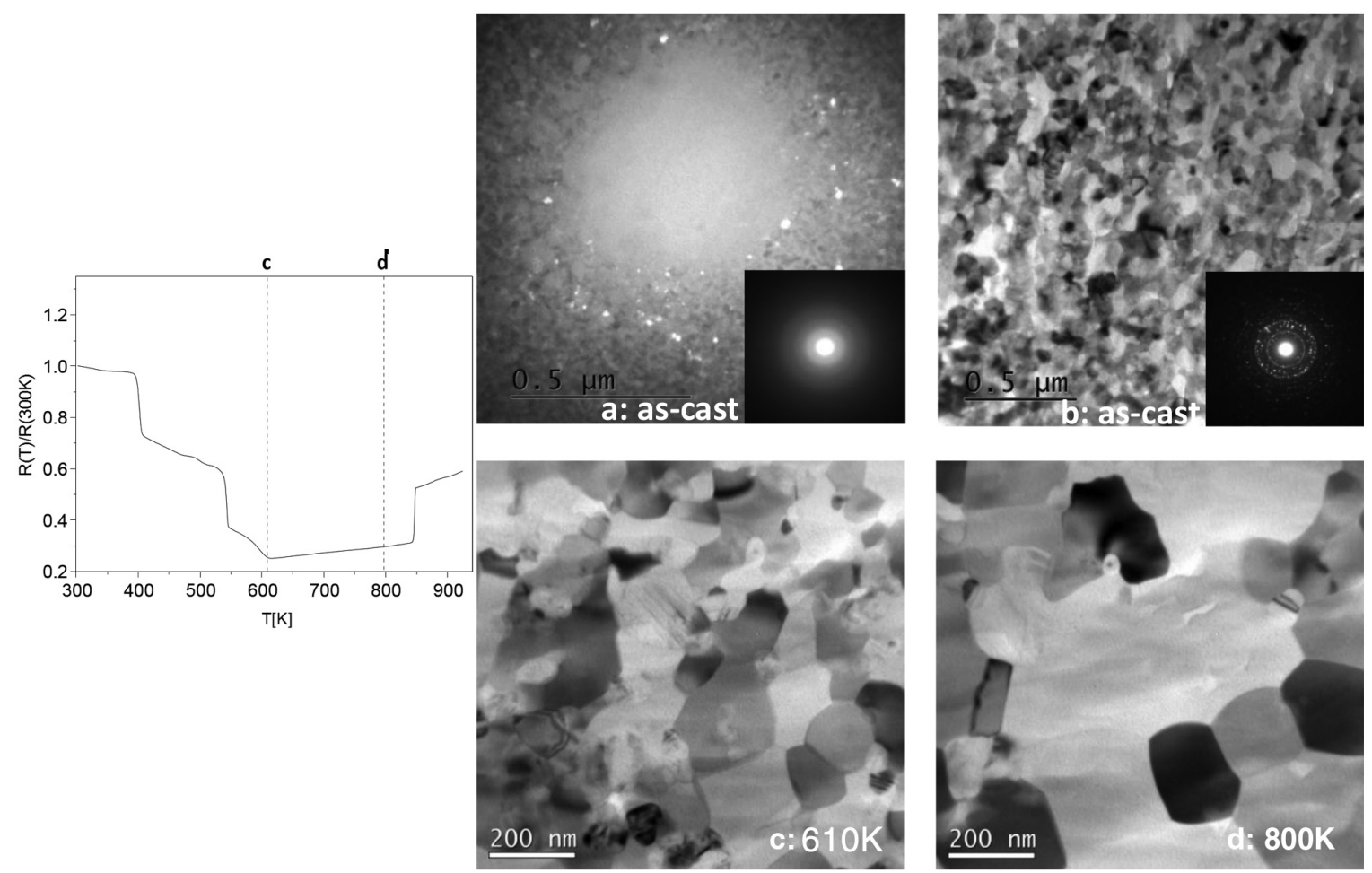

Figure 5. TEM micrographs of $\mathrm{Al}_{75} \mathrm{Ni}_{10} \mathrm{Si}_{20}$ alloy in as-cast state (a), and during in-situ heat treatment at $500 \mathrm{~K}$ (b), $600 \mathrm{~K}$ (c) and $800 \mathrm{~K}$ (d).

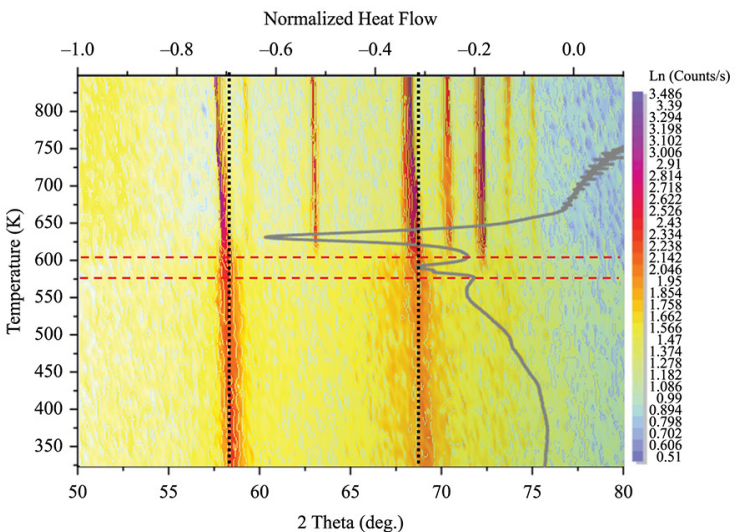

(a)

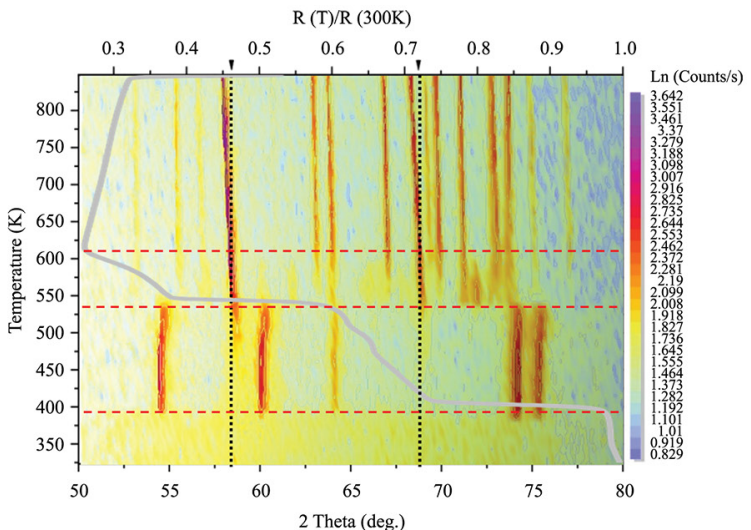

(b)

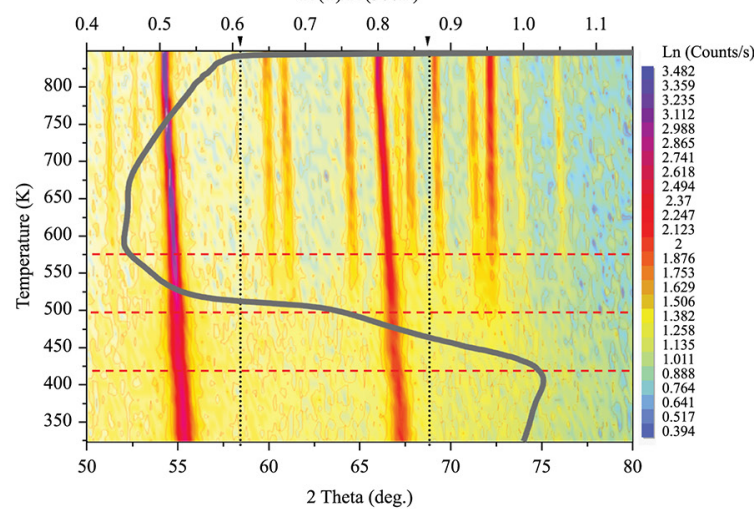

(c)

Figure 6. Overview of XRD patterns of $\mathrm{Al}_{70} \mathrm{Fe}_{10} \mathrm{Si}_{20}$ (a), $\mathrm{Al}_{70} \mathrm{Ni}_{10} \mathrm{Si}_{20}$ (b) and $\mathrm{Al}_{75} \mathrm{Ni}_{5} \mathrm{Si}_{20}$ (c) alloys during heat treatment from as-cast state to $853 \mathrm{~K}$. Inset shows DSC curve (a) and resistivity curve (b and c). Dotted lines mark fcc-Al phase peaks. 


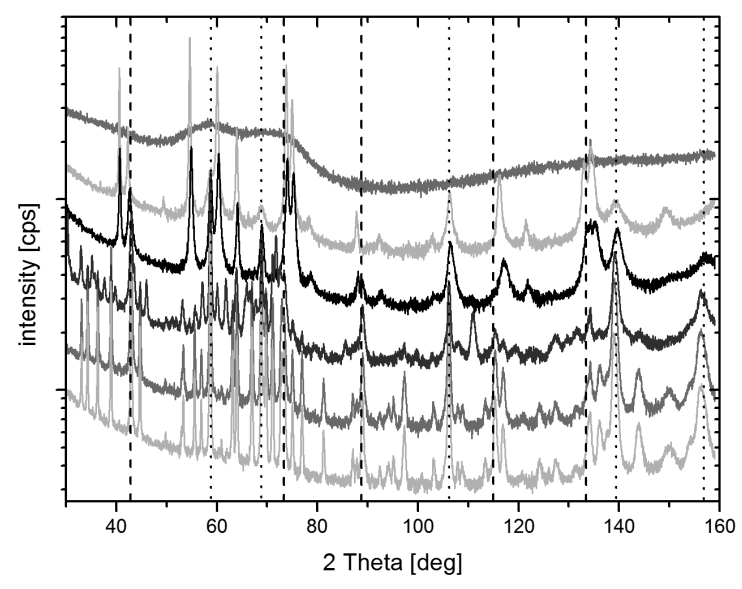

Figure 7. $\mathrm{XRD}$ patterns of $\mathrm{Al}_{75} \mathrm{Ni}_{10} \mathrm{Si}_{20}$ alloy in as-cast state, and during heat treatment at temperatures from $448 \mathrm{~K}$ to $763 \mathrm{~K}$. Dotted lines mark fcc-Al phase peaks, dashed lines mark Si phase peaks.

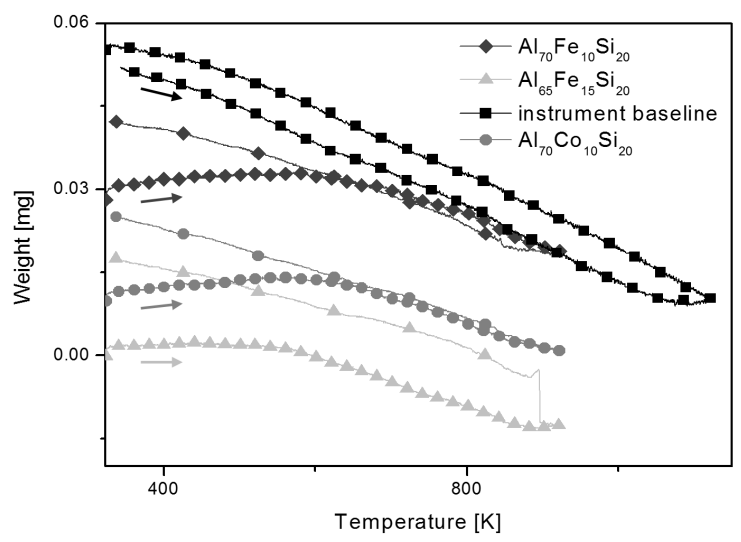

Figure 8. M-TGA measurement of alloys (linear heating $10 \mathrm{~K} / \mathrm{min}$ ). Arrows mark heating parts of curves, cooling curves are without arrows.

\section{References}

1. Long GG, Chapman KW, Chupas PJ, Bendersky LA, Levine LE, Mompiou F, et al. Highly ordered noncrystalline metallic phase. Physical Review Letters. 2013; 111(1):015502. http:// dx.doi.org/10.1103/PhysRevLett.111.015502. PMid:23863012.

2. Park ES and Kim DH. Phase separation and enhancement of plasticity in $\mathrm{Cu}-\mathrm{Zr}-\mathrm{Al}-\mathrm{Y}$ bulk metallic glasses. Acta

\section{Conclusions}

Rapidly quenched systems of Al-Si with addition of Fe, $\mathrm{Ni}$ or Co have been examined. Evolution of relative resistivity with temperature and DSC measurements were obtained to map phase transformations. To qualify phase composition before and after these transformations, phase composition in as-cast state and evolution of phase composition with temperature was observed by in-situ XRD and TEM.

Alloys with 5 at. $\%$ of transition element in as-cast state were composed mostly by fine crystalline fcc-Al and Si phases embedded in amorphous matrix. Interesting amorphous-like areas surrounded by crystalline phase were observed by TEM in initially metastable $\mathrm{Al}_{75} \mathrm{Ni}_{5} \mathrm{Si}_{20}$, which disintegrated during heating. By increasing content of transition element to 10 at.\%, mainly amorphous metastable phases was observed in as-cast state. In-situ XRD analysis of $\mathrm{Al}_{70} \mathrm{Fe}_{10} \mathrm{Si}_{20}$ demonstrated high temperature stability of the initial phase up to approximately $575 \mathrm{~K}$. $\mathrm{Al}_{70} \mathrm{Ni}_{10} \mathrm{Si}_{20}$ transforms at lower temperatures several times to form fcc- $\mathrm{Al}$ and $\mathrm{Al}_{3} \mathrm{Ni}$ phases. Structure morphology and electron diffraction patterns of this sample were observed by in-situ TEM.

Incorporation of $\mathrm{Si}$ into other phases was achieved by rapid quenching of $\mathrm{Al}_{80-\mathrm{x}} \mathrm{T}_{\mathrm{x}} \mathrm{Si}_{20}$ alloys $(\mathrm{T}=\mathrm{Fe}, \mathrm{Ni}, \mathrm{Co})$ with content of transition element (x) between 5 and 10 at.\%. This can help to eliminate Si dendrites in Al-Si based alloys and potentially enhance mechanical properties.

\section{Acknowledgements}

This work was supported by the Slovak Scientific Grant Agency (VEGA 2/0189/14), Slovak Research and Development Agency (APVV-0492-11, APVV-0647-10, APVV-0076-11) and by the Center of Excellence for Functional Materials.

Materialia. 2006; 54(10):2597-2604. http://dx.doi.org/10.1016/j. actamat.2005.12.020.

3. Chapman KW, Chupas PJ, Long GG, Bendersky LA, Levine LE, Mompiou F, et al. An ordered metallic glass solid solution phase that grows from the melt like a crystal. Acta Materialia. 2014; 62:58-68. http://dx.doi.org/10.1016/j.actamat.2013.08.063.

4. Yamamoto A and Tsubakino H. A19Ni2 precipitates formed in an Al-Ni dilute alloy. Scripta Materialia. 1997; 37(11):17211725. http://dx.doi.org/10.1016/S1359-6462(97)00329-1. 